\title{
HUBUNGAN TINGKAT KECERDASAN EMOSIONAL DENGAN TINGKAT STRES PADA PENDERITA DIABETES MELLITUS DI RUMAH SAKIT TENTARA Dr.SOEPRAOEN MALANG
}

\author{
Lilik Supriati $^{\star} \bowtie$, Bintari Ratih Kusumaningrum ${ }^{*}$, Haris Fadjar Setiawan*
}

\begin{abstract}
Abstrak
Diabetes mellitus (DM) merupakan penyakit degeneratif yang memerlukan penanganan tepat dan serius. Penderita DM harus menjalani terapi yang dilakukan secara terus menerus. Kondisi ini dapat mengakibatkan berbagai perubahan kesehatan yang menimbulkan gangguan fisik maupun psikologis bagi penderita. Gangguan psikologis yang umum terjadi yaitu stres. Salah satu faktor yang mempengaruhi stres adalah kecerdasan emosi. Kecerdasan emosi merupakan kemampuan seseorang untuk mengendalikan emosi. Tujuan penelitian ini adalah menganalisis hubungan antara tingkat kecerdasan emosional dengan tingkat stres pada penderita diabetes mellitus. Desain penelitian yang digunakan adalah deskriptif analitik korelasi dengan pendekatan cross sectional. Teknik sampling menggunakan purposive sampling dengan 46 responden. Instrumen yang digunakan adalah kuisioner tingkat kecerdasan emosi dan tingkat stres pada penderita DM. Hasil uji korelasi Spearman menunjukkan bahwaada korelasi negatif antara kecerdasan emosi dengan tingkat stres pada pasien DM $(r=-0,523, p=0,00)$. Penelitian ini menyimpulkan bahwa semakin rendah tingkat kecerdasan emosional semakin tinggi tingkat stres yang dialami penderita DM.
\end{abstract}

Kata kunci: diabetes mellitus (DM), kecerdasan emosional, stres

\section{RELATIONSHIP BETWEEN INTELLIGENCE QUOTIENT EMOTIONAL AND STRESS LEVELS IN PATIENTS WITH DIABETES MELLITUS (DM)AT ARMY HOSPITAL Dr. SOEPRAOEN MALANG}

\begin{abstract}
Diabetes mellitus (DM) is a degenerative disease that requires proper and serious treatment. Patients with diabetes should have continuous therapy. This condition can lead to various health changes that cause physical and psychological disorders for patients like stress. One of the factors that affect the stress is emotional intelligence. Emotional intelligence is a person's ability to control emotions. The aim of this research was to know the relationship between emotional intelligence and stress levels in patients with diabetes mellitus. The design of this research was descriptive analytic correlation using cross sectional approach. The purposive sampling was used for technique sampling with 46 respondents. The instrument used was questionnaire to measure the level of emotional intelligence and stress in patients with DM. The result of Spearman correlation test showed the negative correlation between thetwo variables $(r=-0.523, p=$ 0.00 ). Therefore, the conclusion of this research is that decreasing level of emotional intelligence correlates with increasing levels of stress in DM patients.
\end{abstract}

Keywords: diabetes mellitus, emotional intelligence, stress

* Program Studi IImu Keperawatan, FKUB

『E-mail: lylyiex@yahoo.co.id 


\section{Pendahuluan}

Diabetes mellitus (DM) adalah salah satu penyakit kronis yang sering ditemukan di abad ke-21. ${ }^{1}$ DM adalah kumpulan gejala yang timbul diakibatkan oleh peningkatan kadar gula (glukosa) dalam darah akibat kekurangan hormon insulin secara absolut atau relatif. ${ }^{2}$ Menurut World Health Organization (WHO) jumlah penderita DM di indonesia mencapai 8,4 juta dan diprediksikan jumlah ini akan meningkat menjadi 21,3 juta pada 2030. Indonesia adalah negara ke-enam dengan jumlah penderita diabetes terbanyak di dunia. ${ }^{3}$

Berdasarkan data RISKESDAS (2007), penderita DM di Daerah Istimewa Yogyakarta adalah sebesar 2,6\%, DKI Jakarta sebesar $2,5 \%$, Sulawesi Utara sebesar $2,4 \%$ dan Kalimantan Timur sebesar 2,3\%. Prevalensi diabetes yang terdiagnosis dokter atau gejala, tertinggi terdapat di Sulawesi Tengah (3,7\%), diikuti Sulawesi Utara (3,6\%), Sulawesi Selatan $(3,4 \%)$ dan Nusa Tenggara Timur $3,3 \%$. Prevalensi DM berdasarkan diagnosis dokter dan gejala, meningkat sesuai dengan bertambahnya umur, namun mulai umur $\geq 65$ tahun cenderung menurun. ${ }^{4}$

DM terbagi menjadi 2 tipe yaitu tipe 1 dan tipe 2. Individu yang menderita DM tipe 1 memerlukan suplai insulin dari luar (insulin eksogen), untuk mempertahankan hidup. Sedangkan individu dengan DM tipe 2 resisten terhadap insulin, yaitu suatu kondisi tubuh atau jaringan tubuh yang tidak berespons terhadap aksi dari insulin. Individu dengan DM tipe 2 harus selalu menjaga pola makan, mecegah terjadinya hipoglikemia dan hiperglikemia. Hal tersebut akan berlangsung secara terus menerus sepanjang hidupnya. ${ }^{5}$

Berbagai perubahan kesehatan akan dapat menimbulkan gangguan fisik maupun psikologis bagi penderita. Penderita DM harus tergantung pada terapi pengelolaan DM. Hal tersebut dapat menimbulkan permasalahan stres seperti kepatuhan pengobatan dan manajemen lainnya. Setiap perubahan dalam kesehatan dapat menjadi stressor yang bisa menyebabkan stres pada penderita DM. ${ }^{6}$ Stres merupakan efek dari tubuh yang dianggap berbahaya atau sulit, misalnya tuntuntan pekerjaan dan peran dalam lingkungan tertentu, sedangkan dari dalam biasanya berkaitan dengan keinginan, harapan, dan target yang ingin segera dicapai. ${ }^{7}$

Pada penderita DM, stres dapat menyebabkan perubahan kadar glukosa dalam darah. Saat stres kelenjar adrenal menghasilkan hormon kortisol. Hormon kortisol adalah hormon steroid dari golongan glukortikoid. Fungsi utama hormon kortisol yaitu meningkatkan gula darah dengan mengorbankan jaringan otot, danpada kondisi kronis hormon kortisol dapat mengakibatkan resistensi insulin. ${ }^{8}$

Pada penelitian yang dilakukan pada bulan April 2011 di RSUD Arifin Achmad Pekanbaru, tingkat stres pada penderita DM tipe 2 dari 30 responden adalah 12 orang atau sekitar $40 \%$ mengalami stres rendah, 2 atau $6,7 \%$ orang mengalami stres sedang, dan 16 orang atau $53,3 \%$ mengalami tingkat stres yang tinggi. ${ }^{5}$ Sedangkan penelitian yang dilakukan oleh Wulandari (2013) di RSUD Dr. Haryoto Lumajang dari 99 responden didapatkan $36 \%$ mengalami stres tinggi, dan $10 \%$ mengalami stres sangat tinggi. ${ }^{9}$

Tinggi atau rendahnya stres dipengaruhi oleh reaksi individu itu sendiri terhadap stressor. ${ }^{10}$ Stres cenderung disertai oleh emosi. Seseorang sering menggunakan emosi mereka untuk menilai kondisi stres yang dialami. Menurut Rahmawati (2015), emosi dapat dikontrol dengan tingkat kecerdasan emosional yang tinggi. ${ }^{11}$

Aspek kecerdasan emosional lainnya adalah motivasi diri, seseorang yang memiliki motivasi diri yang tinggi akan cenderung memiliki pandangan positif dalam menilai sesuatu yang terjadi di dalam dirinya, sehingga akan berhubungan dengan perasaan putus asa yang dialami penderita DM dalam menjalani terapinya. ${ }^{12}$ 
Kecerdasan emosional yang buruk dapat menyebabkan masalah pada penderita DM yaitu stressor yang berakibat pada kurangnya manajemen pengendalian glukosa dalam darah, dimana glukosa darah yang tinggi dapat menyebabkan komplikasi yang lain pada penderita DM. Penelitian Dubey (2013) yang membahas tentang hubungan antara tingkat kecerdasan emosional dengan strategi koping penderita DM menunjukkan hasil bahwa seseorang yang memiliki kecerdasan emosional yang baik atau tinggi menunjukkan strategi koping yang adaptif dan seseorang yang memiliki kecerdasan emosional yang rendah memiliki strategi koping maladaptif. ${ }^{13}$

Berdasarkan penelitian di atas memungkinkan kecerdasan emosional dapat juga mempengaruhi stres, karena stres merupakan keadaan tubuh dalam merespons masalah secara maladaptif. Hasil studi pendahuluan yang telah didapatkan di rumah sakit tentara Dr. Soepraoen adalah 5 orang dari 6 orang penderita DM dinyatakan stres. Hal ini berhubungan dengan masalah yang sering dihadapi yaitu masalah terapi yang lama dan terus menerus, masalah pada efek terapi yang berupa hipoglikemia, dan membatasi makanan. Pasien juga mengungkapkan emosi yang berlebihan dan berefek pada kepatuhan minum obat atau kunjungan yang dilakukan pasien.

Berdasarkan uraian yang telah dipaparkan di atas, maka akan diteliti hubungan antara kecerdasan emosional terhadap tingkat stres pada penderita DM di RST Soepraoen Malang.

\section{Bahan dan Metode}

Penelitian ini menggunakan metode analitik korelasi dengan pendekatan cross sectional. Populasi dalam penelitian ini adalah seluruh penderita diabetes mellitus di Poli Penyakit Dalam RST Soepraoen Malang dengan rata-rata kunjungan pada bulan Desember 2015 sebanyak 52 orang. Besar sampel yang didapatkan dengan menggunakan metode purposive sampling adalah sebesar 46 orang. Penelitian ini dilakukan pada bulan April2016.

Variabel independen adalah kecerdasan emosional. Variabel dependen pada penelitian ini adalah tingkat stres pada penderita diabetes mellitus (DM). Instrumen dalam penelitian ini adalah kuesioner yang sudah diuji validitas dan reabilitas. Lembar kuesioner variabel independen terdiri dari 25 pertanyaan, sedangkan variabel dependen terdiri dari 14 pertanyaan. Kriteria penilaian kecerdasan emosional adalah: $25 \%-50 \%$ dikategorikan rendah, $51 \%-75 \%$ dikategorikan sedang, dan 76\%-100\% dikategorikan tinggi. Kriteria tingkat stres adalah: skor 0-14 dikategorikan normal, 1518 dikategorikan ringan, 19-25 dikategorikan sedang, dan 26-33 dikategorikan berat. Data yang diperoleh selanjutnya dianalisis mengunakan uji rank Spearman.

\section{Hasil}

Distribusi data demografi penderita DM di Rumah Sakit Dr. Soepraoen Malang meliputi jenis usia, jenis kelamin, pendidikan, dan lama diagnosa.

Usia:

Berdasarkan Tabel 1, dapat dilihat bahwa rata-rata usia penderita DM adalah 60 tahun atau dalam kategori lansia awal, paling tua 70 tahun dan paling muda adalah 60 tahun.

Jenis Kelamin:

Tabel 2 menunjukkan bahwa sebagian besar penderita DM berjenis kelamin perempuan yaitu sebanyak 27 responden $(58,7 \%)$.

Pendidikan Terakhir:

Berdasarkan Tabel 3, dapat dilihat bahwa lansia yang mempunyai pendidikan terakhir SD adalah sebanyak 16 orang $(34,8 \%)$. 
Tabel 1 Karakteristik responden berdasarkan usia

\begin{tabular}{c|c|c|c|c|c}
\hline Variabel & $\begin{array}{c}\text { Jumlah } \\
\text { Responden }\end{array}$ & $\begin{array}{c}\text { Mean } \\
\text { (tahun) }\end{array}$ & $\begin{array}{c}\text { Maximum } \\
\text { (tahun) }\end{array}$ & $\begin{array}{c}\text { Minimum } \\
\text { (tahun) }\end{array}$ & $\begin{array}{c}\text { Std. } \\
\text { Deviation }\end{array}$ \\
\hline Usia & 46 & 60 & 70 & 40 & 8,301 \\
\hline
\end{tabular}

Tabel 2. Karakteristik responden berdasarkan jenis kelamin

\begin{tabular}{cccc}
\hline $\begin{array}{c}\text { Karakteristik } \\
\text { PenderitaDM }\end{array}$ & Kategori & Jumlah & $\begin{array}{c}\text { Persentase } \\
(100 \%)\end{array}$ \\
\hline \multirow{2}{*}{ Jenis Kelamin } & Laki-laki & 19 & 41,3 \\
& Perempuan & 27 & 58,7 \\
\hline & Total & 46 & 100.00 \\
\hline
\end{tabular}

Tabel 3. Karakteristik responden berdasarkan pendidikan terakhir

\begin{tabular}{llcc}
\hline $\begin{array}{c}\text { Karakteristik } \\
\text { PenderitaDM }\end{array}$ & Kategori & Jumlah & $\begin{array}{c}\text { Persentase } \\
(100 \%)\end{array}$ \\
\hline \multirow{3}{*}{ Pendidikan } & SD & 16 & 34,8 \\
terakhir & SMP & 12 & 26,1 \\
& SMA & 14 & 30,4 \\
& Perguruantinggi & 4 & 8,7 \\
\hline & Total & 46 & 100,00 \\
\hline
\end{tabular}

Lamanya Terdiagnosa Diabetes Mellitus:

Berdasarkan Tabel 4, menunjukkan bahwa rata-rata lama penderita DM terdiagnosa yaitu selama 43 bulan, paling lama 8 tahun dan paling sebentar 6 bulan, dengan nilai standar deviasi adalah 26,951.

Tabel 4. Karakteristik responden berdasarkan lamanya terdiagnosa

\begin{tabular}{ccccc}
\hline Variabel & N & Mean & Minimum-maximum & Std. deviasi \\
\hline Lama sakit & 46 & 43 bulan & 6 bulan - 8 tahun & 26,951 \\
\hline
\end{tabular}

Tabel 5. Distribusi frekuensi tingkat kecerdasan emosi

\begin{tabular}{lcc}
\hline Tingkat Kecerdasan Emosi & Frekuensi & Prosentase \\
\hline Tingkat Kecerdasan Emosi Rendah & 22 & $47,8 \%$ \\
Tingkat Kecerdasan Emosi Sedang & 18 & $39,1 \%$ \\
Tingkat Kecerdasan Emosi tinggi & 6 & $13 \%$ \\
Total & 46 & 100,00 \\
\hline
\end{tabular}

Tingkat Kecerdasan Emosional:

Berdasarkan Tabel 5, dapat diketahui bahwa tingkat kecerdasan emosional yang didapatkan pada penderita DM paling banyak adalah tingkat kecerdasan emosional rendah sebanyak 22 responden (47,8\%). Selanjutnya secara khusus tingkat kecerdasan emosional dibagi menjadi 5 indikator yaitu mengenali emosi, mengelola emosi, memotivasi diri, 
mengenali emosi orang lain, membina

hubungan sosial. Untuk mengetahui

bagaimana gambaran tingkat kecerdasan emosi pada masing-masing indikator dapat dilihat pada Tabel 6 berikut.

Tabel 6. Distribusi frekuensi indikator tingkat kecerdasan emosional

\begin{tabular}{|c|c|c|c|c|c|c|c|c|}
\hline \multirow{2}{*}{$\begin{array}{c}\text { Kecerdasan } \\
\text { emosi }\end{array}$} & \multicolumn{2}{|c|}{ Tinggi } & \multicolumn{2}{|c|}{ Sedang } & \multicolumn{2}{|c|}{ Rendah } & \multicolumn{2}{|c|}{ Total } \\
\hline & $\mathrm{F}$ & $\%$ & $\mathrm{~F}$ & $\%$ & $\mathrm{~F}$ & $\%$ & $\mathrm{~F}$ & $\%$ \\
\hline $\begin{array}{c}\text { Mengenali } \\
\text { emosi }\end{array}$ & 3 & 6,5 & 27 & 58,7 & 16 & 34,8 & 46 & 100 \\
\hline $\begin{array}{c}\text { Mengelola } \\
\text { emosi }\end{array}$ & 2 & 4,3 & 19 & 41,3 & 25 & 54,3 & 46 & 100 \\
\hline Memotivasi diri & 1 & 2,2 & 28 & 60,9 & 17 & 37,0 & 46 & 100 \\
\hline $\begin{array}{c}\text { Mengenali } \\
\text { emosi orang lain }\end{array}$ & 3 & 6,5 & 27 & 58,7 & 16 & 34,8 & 46 & 100 \\
\hline $\begin{array}{c}\text { Membina } \\
\text { hubungan sosial }\end{array}$ & 3 & 6,5 & 24 & 52,2 & 19 & 41,3 & 46 & 100 \\
\hline
\end{tabular}

Berdasarkan Tabel 6, dapat diketahui bahwa pada kategori "tinggi", tingkat kecerdasan emosi yang paling mendominasi adalah mengenali emosi, mengenali emosi orang lain, membina hubungan sosial yaitu sebanyak 3 orang $(6,5 \%)$. Pada kategori "sedang", diketahui bahwa kecerdasan emosi yang paling mendominasi adalah memotivasi diri dengan jumlah $28(60,9 \%)$, dan pada kategori "rendah"diketahui bahwa tingkat kecerdasan emosi yang mendominasi adalah mengelola emosi diri dengan jumlah 25 orang $(54,3 \%)$.

Tingkat stres

Pada Tabel 7 diketahui bahwa dari 5 klasifikasi tingkat stres penderita DM dalam kategori normal sebanyak 5 responden $(10,9 \%)$, stres ringan sebanyak 8 responden $(17,4 \%)$, sedangkan stres sedang dialami oleh 16 responden $(34,8 \%)$, dan stres berat dialamioleh17 responden (37\%).

Tabel 7. Distribusi frekuensi tingkat stres

\begin{tabular}{lcc}
\hline Tingkat stres & Frekuensi & Prosentase $(\%)$ \\
\hline Normal & 5 & $10,9 \%$ \\
Ringan & 8 & $17,4 \%$ \\
Sedang & 16 & $34,8 \%$ \\
Berat & 17 & $37 \%$ \\
total & 46 & $100 \%$ \\
\hline
\end{tabular}

Analisis hubungan tingkat kecerdasan emosional dengan tingkat stres pada penderita DM: 
Tabel 8. Hubungan tingkat kecerdasan emosional dengan tingkat stres pada penderita DM

\begin{tabular}{|c|c|c|c|c|c|c|c|c|c|c|c|c|}
\hline \multirow[t]{2}{*}{ Yariabel } & \multicolumn{2}{|c|}{$\begin{array}{l}\text { Tingkat } \\
\text { stres } \\
\text { normal }\end{array}$} & \multicolumn{2}{|c|}{$\begin{array}{c}\text { Tingkat } \\
\text { stres } \\
\text { ringan }\end{array}$} & \multicolumn{2}{|c|}{$\begin{array}{l}\text { Tingkat } \\
\text { stres } \\
\text { sedeng }\end{array}$} & \multicolumn{2}{|c|}{$\begin{array}{l}\text { Tingkat } \\
\text { Stres } \\
\text { perat }\end{array}$} & \multirow[t]{2}{*}{$\mathrm{N}$} & \multirow[t]{2}{*}{$\%$} & \multirow[t]{2}{*}{$\begin{array}{c}\text { Koefisien } \\
\text { korelasi } \\
R\end{array}$} & \multirow[t]{2}{*}{$\begin{array}{c}P \\
\text { Value }\end{array}$} \\
\hline & $F$ & \% & $F$ & $\%$ & $F$ & $\%$ & $F$ & $\%$ & & & & \\
\hline $\begin{array}{l}\text { Tingkat } \\
\text { kecerdasan } \\
\text { emosional } \\
\text { rendah }\end{array}$ & 0 & 0 & 1 & 2,2 & 9 & 19,6 & 12 & 26,1 & 22 & 47,8 & & \\
\hline $\begin{array}{l}\text { Tingkat } \\
\text { kecerdasan } \\
\text { emosional } \\
\text { sedang }\end{array}$ & 3 & 6,5 & 4 & 8,7 & 7 & 15.2 & 4 & 8,7 & 18 & 39,1 & $-0,523$ & 0,000 \\
\hline $\begin{array}{l}\text { Tingkat } \\
\text { kecerdasan } \\
\text { emosional } \\
\text { tinggi }\end{array}$ & 2 & $4.3 \%$ & 3 & 6,5 & 0 & 0 & 1 & 2.2 & 6 & 13 & & \\
\hline TOTAL & 5 & & 8 & & 16 & & 17 & & 46 & 100 & & \\
\hline
\end{tabular}

Dari Tabel 8 didapatkan nilai koefisien korelasi ( $r$ ) antara tingkat kecerdasan emosional dengan tingkat stres adalah $-0,523$. Nilai tersebut menunjukkan bahwa ada hubungan yang cukup kuat antara tingkat kecerdasan emosional dengan tingkat stres. Hubungan antara kedua variabel adalah berlawanan (negatif) yang artinya semakin rendah tingkat kecerdasan emosional akansemakin tinggi tingkat stres.

\section{Pembahasan}

Tingkat Kecerdasan Emosional pada PenderitaDM di Rumah Sakit Tentara Dr. Soepraoen Malang:

Hasil penelitian tingkat kecerdasan emosional di Poli Penyakit Dalam di Rumah Sakit Tentara Dr. Soepraoen menunjukan bahwa sebagian besar penderita DM memiliki tingkat kecerdasan emosional yang rendah, yaitu sebanyak 22 responden $(47,8 \%)$, sedangkan tingkat kecerdasan emosi sedang sebanyak 18 responden $(39,1 \%)$ dan tingkat kecerdasan emosi tinggi sebanyak 6 responden(13\%).

Salah satu faktor yang mempengaruhi kecerdasan emosional yaitu tingkat pendidikan. Hasil penelitian yang telah dilakukan menunjukkan sebagian besar responden memiliki tingkat pendidikan SD yaitu 16 responden $(34,8 \%)$. Hal ini sejalan dengan penelitian sebelumnya yang menyatakan bahwa didapatkan hasil positif antara tingkat kecerdasan emosional dengan tingkat pendidikan. ${ }^{14}$ Sementara itu, penelitian lain menunjukkan bahwa tingkat kecerdasan emosional yang tinggi pada pasien dengan tingkat pendidikan terakhir sarjana. ${ }^{15}$ Sehingga dapat ditarik kesimpulan bahwa tingkat pendidikan terakhir merupakan salah satu faktor yang mempengaruhi tingkat kecerdasan emosional. Hal ini dikarenakan pendidikan dapat menjadi salah satu sarana belajar individu untuk mengembangkan kecerdasan emosi. Faktor lain yang mempengaruhi tingkat kecerdasan emosional adalah usia. Dari hasil penelitian didapatkan tingkat kecerdasan emosional yang rendah dengan data rata-rata usia responden yaitu 60 tahun. Tingkat kecerdasan emosional yang baik umumnya pada rentan usia 18-35 tahun. ${ }^{15}$ Dengan demikian, dapat disimpulkan bahwa terdapat hubungan antara tingkat kecerdasan emosi dengan usia.

Hasil penelitian ini menunjukkan bahwa 
berdasarkan jenis kelamin sebagian besar responden berjenis kelamin perempuan yaitu $58,7 \%$ memiliki kecerdasan emosional yang rendah. Hal tersebut tidak sejalan dengan pernyataan Goleman (2015) bahwa kecerdasan emosional perempuan lebih baik dibandingkan laki-laki karena perempuan lebih dapat merasakan emosi positif maupun negatif dan perempuan juga memiliki kehidupan emosional yang lebih baik. ${ }^{12}$ Perbedaan hasil penelitian tersebut terjadi kemungkinan karena faktor-faktor lain yang dapat mempengaruhi tingkat kecerdasan emosional seseorang seperti faktor usia dan tingkat pendidikan terakhir.

Hasil penelitian inijuga menunjukkan tingkat kecerdasan emosional yang rendah pada pengelolaan emosi yaitu pada sekitar $54,3 \%$ responden. Pada penderita diabetes mengalami banyak perubahan di dalam hidupnya seperti harus menerima kenyataan bahwa klien menderita diabetes dan harus menjalani terapi secara terus menerus. Hal ini sesuai dengan teori yang dikemukakan oleh Goleman (2015) bahwa mengelola emosi adalah pengelolaan impuls dan perasaan yang menekan dan orang yang buruk kemampuannya dalam mengelola emosi akan terus menerus bertarung melawan perasaan murung atau melarikan diri pada hal-hal yang merugikan diri sendiri. ${ }^{12}$

Tingkat Stres Pada Penderita Diabetes Mellitus di Rumah Sakit Tentara Dr. Soepraoen:

Hasil penelitian tingkat stres di Poli Penyakit Dalam Rumah Sakit Tentara Dr Soepraoen menunjukkan bahwa penderita DM yang memiliki tingkat stres berat yaitu $37 \%$, sedangkan tingkat stres sedang $34,8 \%$, serta tingkat stres ringan sebanyak 8 responden $(10,9 \%)$ dan tingkat stres normal sebanyak $(10,9 \%)$. Hal ini kemungkinan disebabkan karena terapi diabetes yang harus dijalani oleh penderita secara terus menerus. Faktor pemberat lainnya yang juga mempengaruhi stres yang dirasakan penderita yaitu lamanya diagnosa penyakit DM.

Penelitian ini juga menunjukkan bahwa penderita DM di RST Dr. Soepraoen Malang sebagian besar terdiagnosa DM rata-rata selama 3,7 tahun dengan tingkat stres yang tinggi. Hasil tersebut didukung oleh Wulandari (2013) yang menyebutkan bahwa rata-rata lama terdiagnosa DM selama lebih dari 5 tahun, namun dengan tingkat stres yang rendah. ${ }^{9} \mathrm{Hal}$ ini menunjukkan bahwa semakin lama penderita DM menjalani terapi maka penderita menjadi dapat beradaptasi, sehingga mengalami stres yang rendah.

Faktor lain yang mempengaruhi tingkat stres yaitu usia. Hasil penelitian menunjukan bahwa kategori usia responden penderita DM paling banyak yaitulebih dari 61 tahun $(60,9 \%)$, dengan tingkat stres berat yaitu sebanyak $52 \%$, dan usia responden di atas 56 tahun adalah $50 \%$ dari total 48 responden. Pada usia lansia yaitu $>50$ tahun umumnya mengalami penurunan kondisi fisik, psikologis yang diperparah dengan adanya perubahan dalam hidup, misalnya perubahan yang berkaitan dengan pekerjaan atau stres, perubahan peran stres di masyarakat menyebabkan timbulnya masalah diantaranya stres.

Hubungan Tingkat Kecerdasan Emosional Dengan Tingkat Stres Pada PenderitaDM di Rumah Sakit Tentara Dr Soepraoen Malang:

Hasil uji korelasi Spearman menunjukkan adanya hubungan antara tingat kecerdasan emosional dengan tingkat stres pada penderita DM $(R=-0,523, p=0,00)$. Pada penderita DM yang memiliki kecerdasan emosional yang rendah cenderung mengalami stres tinggi dan pada penderita DM yang memiliki kecerdasan emosional yang tinggi cenderung mengalami stres yang ringan. Hal ini dikarenakan penderita DM harus menjaga pola makan, selalu melakukan perawatan kaki, mencegah terjadinya hipoglikemia dan hiperglikemia. Hal tersebut akan berlangsung secara terus menerus sepanjang hidupnya. Tinggi atau rendahnya stres dipengaruhi oleh reaksi individu itu sendiri terhadap stressor. ${ }^{10}$

Stres cenderung disertai dengan emosi, maka seseorang akan sering menggunakan 
emosi mereka untuk menilai kondisi stres yang dialami. Tingkat stres pada penderita DM dapat mengalami kemunduran dari segi fisik dan psikologis, seorang penderita diabetes mellitus pada umumnya juga mengalami kemunduran dari segi emosional. Segi emosional tersebut meliputi sikap menyangkal, obsesif dan takut. Emosi dapat dikontrol dengan tingkat kecerdasan emosional yang tinggi. ${ }^{11}$

Individu dengan kecerdasan emosional yang tinggi mengalami sedikit respons emosional negatif yang memungkinkan mereka untuk beradaptasi lebih mudah. Kecerdasan emosional yang rendah juga dapat mempengaruhi terapi pengobatan DM karena seseorang yang memiliki penyakit kronis selalu sulit untuk menerima kenyataan bahwa mereka harus melakukan perubahan gaya hidup. Hal ini disebabkan pasien biasanya sadar bahwa mereka rentan terhadap penyakit lanjut dan harapan mereka untuk hidup menjadi lebih pendek. ${ }^{16}$

Stres bisa memiliki konsekuensi secara emosional yaitu dapat mengakibatkan perasaan negatif, mempengaruhi kemampuan memecahkan masalah, dan mengubah hubungan seseorang dengan orang lain. ${ }^{16}$ Komponen kecerdasan emosional yaitu kesadaran diri, pengaturan diri, serta hubungan sosial. Kesadaran diri adalah kemampuan dalam mengenali perasaan dalam diri sendiri. Pengaturan diri berarti pengelolaan impuls dan perasaan yang menekan, agar dapat terungkap dengan tepat. Keterampilan sosial merupakan seni dalam membina hubungan dengan orang lain yang mendukung keberhasilan dalam bergaul dengan orang lain. ${ }^{12}$ Stres dapat mengganggu cara seseorang dalam menyerap realita, menyelesaikan masalah, berpikir secara umum, dan hubungan seseorang dan rasa memiliki. Selain itu, stres dapat mengganggu pandangan umum seseorang terhadap hidup, sikap yang ditunjukkan pada orang yang disayangi dan status kesehatan. ${ }^{6}$ Beberapa aspek stres yaitu biologis dan psikososial. Aspek psikososial itu sendiri terdiri dari kognitif, emosi, dan sosial.

\section{Kesimpulan}

Kesimpulan dari penelitian ini adalah kecerdasan emosional di Poli Penyakit Dalam Rumah Sakit Tentara Dr. Soepraoen Malang yaitutingkat kecerdasan emosional rendah padasebanyak 22 responden(47,8\%), dan tingkat stres berat dialami oleh17 responden (37\%). Terdapat hubungan cukup kuat antara tingkat kecerdasan emosional dengan tingkat stres, semakin rendah tingkat kecerdasan emosional semakin tinggi tingkatstres.

\section{Saran}

Berdasarkan hasil penelitian maka diharapkan petugas kesehatan dapat meningkatkan peran dalam edukasi kepada pasien DM untuk melakukan pengendalian emosi sehingga bisa menurunkan stres dan pengobatan dapat dillakukan dengan maksimal. Bagi penelitian selanjutnya disarankan untuk menggunakan metode eksperimen untuk membantu pasien DM dalam melakukan manajemen pengendalian emosi dan penurunan stres.

\section{Daftar Pustaka}

1. Tandra H. Segala Sesuatu yang Harus Anda Ketahui Tentang Diabetes Tanya Jawab Lengkap Dengan Ahlinya. Jakarta: Gramedia. 2008.

2. Almatsier S. Penuntun Diet. Jakarta: Gramedia Pustaka Utama. 2006.

3. Kariadi S dan Hartini KS. Diabetes? Siapa Takut!!. Bandung: Penerbit Qanita. 2009.

4. RISKESDAS.2007. Online. Http://Digilib.Esaunggul.Ac.Id/Public/UEU -Undergraduate 2405BABI.Pdf?Kbzahyuoccezfbza. Diakses 24 Januari2016.

5. Sofiana LI, Elita V, dan Utomo W. Hubungan antara Stres dengan Konsep Diri pada Penderita Diabetes Mellitus Tipe 
2. Jurnal Ners Indonesia.2012; 2(2).

6. Perry AG dan Potter PA. Buku Ajar Fundamental Keperawatan: Konsep, Proses dan Praktik. Jakarta: EGC.2008.

7. Ide P. Seri Bodytalk-Yoga untuk Stres. Jakarta: Gramedia. 2008.

8. Tiedt JA and Brown LA. Allostatic Load: The Relationship between Chronic Stress and Diabetes in Native Americans. Journal of Theory Construction \& Testing. 2014; 18(22).

9. Wulandari CD. Hubungan antara Persepsi terhadap Penyakit dengan Tingkat Stres pada Penderita Diabetes Mellitus Tipe II di RSD Dr. Haryoto Lumajang. Malang: Universitas Brawijaya. 2013.

10. Lahey BB. Psychology An Introduction. $9^{\text {th }}$ Edition. New York: Mcgraw-Hill Companies. 2007.

11. Rahmawati RC. Hubungan Tingkat Kecerdasan Emosional dengan Tingkat Stres Akademik pada Remaja Menjelang Ujian Nasional (Studi Kasus di SMA Negeri 3 Lumajang). Malang: Universitas Brawijaya. 2015.

12. Goleman D. Emotional Intelegence.
Jakarta: PT Gramedia. 2015.

13. Dubey A. Fostering Emotional Intelligence and Coping with Diabetes and Evaluation of Quality of Life. Indian Journal of Health and Wellbeing. 2013.

14. Tri KAR. Efek Gender dan Pendidikan pada Hubungan Kecerdasan Emosional dan Kinerja Karyawan BPR di Kabupaten Gianyar. Bali: Universitas Udayana. 2010.

15. Donahue AS.The Relationship among Emotional Intelligence, SelfManagement and Glycemic Control in Individuals with Type 1 Diabetes.US: University Of Massachusetss Worcester. 2010.

16. Isworo A. Hubungan Depresi dan Dukungan Keluarga terhadap Kadar Gula Darah pada Pasien Diabetes Mellitus Tipe 2 Di RSUD Sragen. Purwokerto: Universitas Jendral Soedirman. 2010.

17. Sarafino EP and Smith TW. Health Psychology: Biopsychosocial Interactions. $7^{\text {th }}$ Edition.US: John Wiley \& Sons Inc. 2011. 